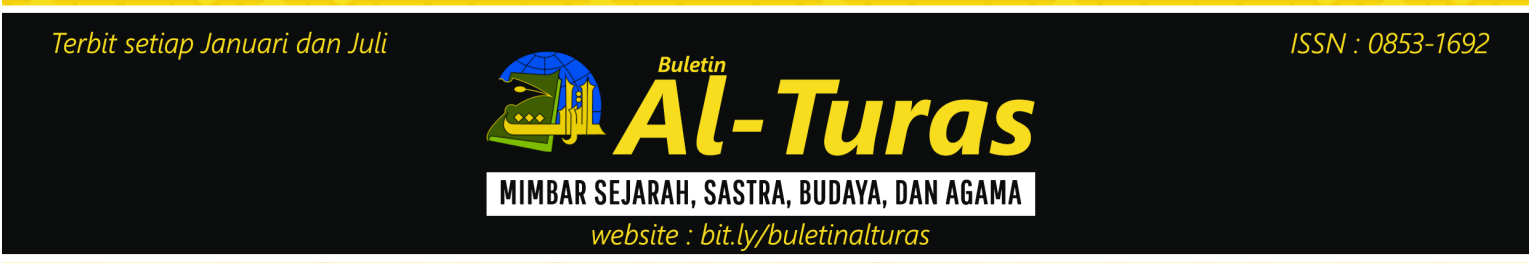

\title{
Hegemoni Oposisi Biner dalam Konten Forum Diskusi E-Learning
}

Ruisah $^{1}$

\section{Abstract}

The development of science and technology, especially information technology, internet use in education continues to grow. Use of the Internet is not just for distance education, but also developed in the conventional education system. E-learning is a learning model that is created in digital format through an electronic device. Purpose of the use of e-learning in the learning system is to expand access to education public, so that learning modules can be accessed easily, without di batasi space and time, interactive, and effective. In this paper a prototype using a software development methodology that emphasizes the approach to aspects of design, functionality and user-interface. The final product is expected to be a module-based learning application of information technology.

Keywords: Internet, the quality of education, information technology, e-learning

\section{Abstrak}

Penelitian ini bertujuan mengkaji adanya hegemoni dalam perkuliahan online atau E-learning, yaitu pembelajaran yang dilakukan di media elektronik internet baik secara formal maupun informal. E-learning yang mengharuskan terjadinya kadar interaksi pembelajaran antara mahasiswa dan dosen dan memungkinkan terjadinya interaksi pembelajaran dalam format forum diskusi, menunjukkan adanya hegemoni terkait oposisi biner antara dua pelaku diskusi. Penelitian ini menerapkan metode deskritif tentang oposisi biner dan hegemoni yang terjadi pada proses diskusi e-learning pada kursus tertentu sebagai data dalam penelitian. Hegemoni menurut Gramsci adalah sebuah pandangan hidup dan cara berpikir yang dominan, yang di dalamnya sebuah konsep tentang kenyataan disebarluaskan dalam masyarakat baik secara institusional maupun perorangan. Dominasi-dominasi tersebutlah yang menjadi fokus dalam penelitian ini.

Kata Kunci: Hegemoni, oposisi biner, e-learning

\footnotetext{
${ }^{1}$ Lecturer of English Department Faculty of Letters, Pamulang University.
} 


\section{A. Pendahuluan}

E-learning dalam arti luas bisa mencakup pembelajaran yang dilakukan di media elektronik internet baik secara formal maupun informal. E-learning secara formal misalnya adalah pembelajaran dengan kurikulum, silabus, mata pelajaran dan tes yang telah diatur dan disusun berdasarkan jadwal yang telah disepakati pihak-pihak terkait yaitu pengelola e-learning dan pembelajar sendiri. Pembelajaran seperti ini biasanya tingkat interaksinya tinggi. E-learning merupakan singkatan dari Elektronic Learning, merupakan cara baru dalam proses belajar mengajar yang menggunakan media elektronik khususnya internet sebagai sistem pembelajarannya. E-learning merupakan dasar dan konsekuensi logis dari perkembangan teknologi informasi dan komunikasi. Beberapa ahli mencoba menguraikan pengertian e-learning menurut versinya masing-masing, di antaranya Jaya Kumar C. Koran (2002) e-learning sebagai sembarang pengajaran dan pembelajaran yang menggunakan rangkaian elektronik (LAN, WAN, atau internet) untuk menyampaikan isi pembelajaran, interaksi, atau bimbingan. ${ }^{2}$ Dong (dalam Kamarga, 2002) e-learning sebagai kegiatan belajar asynchronous melalui perangkat elektronik komputer yang memperoleh bahan belajar yang sesuai dengan kebutuhannya. ${ }^{3}$ Rosenberg (2006: 3) sebagaimana diadaptasikan oleh Putranto menekankan bahwa e-learning merujuk pada penggunaan

${ }^{2} \mathrm{C}$. Jaya Kumar Koran. "Pengertian E-Learninghttp://www.M.edukasi.Web. Id/2012/11/Pengertian-e-Learning.Html," 2002, 23.

${ }^{3}$ Hanny Kamaraga, "Belajar Sejarah Melalui E-Learning; Alternatif Mengakses Sumber Informasi Kesejarahan.," Jakarta: Inti Media, 2002, 44. teknologi internet untuk mengirimkan serangkaian solusi yang dapat meningkatkan pengetahuan dan keterampilan. ${ }^{4}$ Darin E. Hartley [Hartley, 2001] e-learning merupakan suatu jenis belajar mengajar yang memungkinkan tersampaikannya bahan ajar ke siswa dengan menggunakan media Internet, Intranet atau media jaringan komputer lain. ${ }^{5}$ LearnFrame.Com dalam Glossary of eLearning Terms [Glossary, 2001] sebagaimana dijelaskan oleh Winarno dan Johan (2013), e-learning adalah sistem pendidikan yang menggunakan aplikasi elektronik untuk mendukung belajar mengajar dengan media Internet, jaringan komputer, maupun komputer standalone. ${ }^{6}$ Secara singkat e-learning adalah pembelajaran yang disusun dengan tujuan menggunakan sistem elektronik atau komputer sehingga mampu mendukung proses pembelajaran, demikian dijelaskan oleh Michael. ${ }^{7}$ Proses pembelajaran jarak jauh dengan menggabungkan prinsipprinsip dalam proses pembelajaran dengan teknologi. ${ }^{8}$ Sistem pembelajaran yang digunakan sebagai sarana untuk proses belajar mengajar yang dilaksanakan tanpa harus bertatap muka secara langsung antara guru dengan

${ }^{4}$ Agus Putranto, "Perancangan Training Dengan E-Learning Pada Perusahaan Manufacture," Junral Comtech Vol. 2, No. 1 Juni 2011 (2011): 317.

${ }^{5}$ Darin E Hartley, "Selling E-Learning, American Society for Training and Development.," 2001, 3.

${ }^{6}$ Winarno and Setiawan Johan, "Penerapan Sistem E -Learning Pada Komunitas Pendidikan Sekolah Rumah (Home Schooling)," Jurnal ULTIMA InfoSys Vol IV, No, 1 (June 2013): 45.

${ }^{7}$ Allen Michael, "Michael Allen's Guide to Elearning. Canada: John Wiley \& Sons.,” 2013, 27.

${ }^{8}$ Sri Rahayu Chandrawati, "Pemanfaatan E-Learning Dalam Pembelajaran.," Juran Untan Vol. 8 No 2 (2010), http://jurnal.untan.ac.id/. 
siswa. ${ }^{9}$

Kuliah online secara dasar pemaknaan terutama pada universitas tertentu yang berbasis daring adalah kuliah tanpa harus menghadiri kelas di kampus, tetapi tetap bisa menikmati fasilitas universitas dan mendapatkan gelar yang sama dengan mahasiswa reguler. Kuliah biasanya disampaikan via teleconference, materi pelajaran disediakan secara online, dan juga terdapat forum dimana mahasiswa dapat mengajukan pertanyaan kepada dosen, dan saling berdiskusi antara satu mahasiswa yang satu dan lainnya. Sistem ini berlaku secara keseluruhan, tidak seperti pada beberapa kampus yang memberlakukan kuliah online pada sebagian pertemuan. Sistem integral yang dimulai dari setelah mendaftar untuk kuliah online, lalu mahasiswa akan diberikan akun untuk $\log$ in di situs, di mana mahasiswa dapat mengakses materi pelajaran yang bisa berupa artikel, atau bacaan elektronik, bahkan video atau rekaman audio kuliah yang disampaikan dosen, mengakses forum tanya jawab dan diskusi antara mahasiswa dan dosen, atau sesama mahasiswa. Pola yang seperti ini adalah sama natra kampus yang menganut konsep online secara keselurahan dan yang sebagian. Semisal pada kampus yang menembus permasalahan jarak atau kuliah ke luar negeri. Dengan kuliah online, asal bisa mengatur waktu dengan baik, maka tetap bisa kuliah tanpa harus meninggalkan aktifitas dan pekerjaan. ini adalah opsi yang sangat baik agar calon mahasiswa dengan kendalakendala tertentu bias tetap kuliah.

${ }^{9}$ Ivan Ardiansyah, Eksplorasi Pola Komunikasi Dalam Diskusi Menggunakan Moddle Pada Perkuliahan Simulasi Pembelajaran Kimia, Universitas Pendidikan Indonesia (Bandung: Universitas Pendidikan Indonesia, 2013).
Menurut Rosenberg (2001) dalam Putranto karakteristik E-learning bersifat jaringan, yang membuatnya mampu memperbaiki secara cepat, menyimpan atau memunculkan kembali, mendistribusikan, dan sharing pembelajaran dan informasi. ${ }^{10}$ Manfaat e-learning (Smaratungga, 2009) terdiri atas 4 hal, yaitu meningkatkan kadar interaksi pembelajaran antara peserta didik dengan guru atau instruktur (enhance interactivity). ${ }^{11}$

Memungkinkan terjadinya interaksi pembelajaran dari mana dan kapan saja (time and place flexibility). Menjangkau peserta didik dalam cakupan yang luas (potential to reach a global audience). Dan Mempermudah penyempurnaan dan penyimpanan materi pembelajaran (easy updating of content as well as archivable capabilities).

E-learning mempermudah interaksi antara peserta didik dengan bahan/materi pelajaran. Demikian juga interaksi antara peserta didik dengan dosen/guru/instruktur maupun antara sesama peserta didik. Peserta didik dapat saling berbagi informasi atau pendapat mengenai berbagai hal yang menyangkut pelajaran ataupun kebutuhan pengembangan diri peserta didik. Mahasiswa kuliah online harus membaca textbook terlebih dahulu sebelum mengikuti kelas online, atau dengan kata lain mereka memiliki kemandirian akademik. Mahasiswa juga harus membuat jadwal sendiri, dan bisa memotivasi sendiri agar bisa menyelesaikan waktu sesuai yang dijadwalkan.

\footnotetext{
${ }^{10}$ Putranto, "Perancangan Training Dengan E-Learning Pada Perusahaan Manufacture," 317.

${ }^{11}$ Smaratungga. Manfaat E-Learning. Medica, Yogyakarta, 2009.
} 


\section{B. Pembahasan}

\section{Oposisi Biner}

Oposisi biner sebenarnya, secara sederhana, dapat diartikan sebagai sebuah sistem yang berusaha membagi dunia dalam dua klasifikasi yang berhubungan secara struktural. Contoh yang sederhana, hubungan antara dosen yang memberikan materi perkuliahan dengan mahasiswa yang menerima materi perkuliahan. Dosen dan mahasiswa secara terminologi sosial memang berlawanan fungsi namun secara struktural, dalam dunia pendidikan, dua eleman ini mutlak ada. Dosen membutuhkan mahasiswa untuk mentranformasikan ilmunya dalam sebuah pembelajaran. Di lain pihak, mahasiswa membutuhkan hadirnya dosen sebagai tempat bertanya dan pembimbing yang mengarahkan studinya. Begitulah realitas kehidupan yang pasti ada dua hal yang berbeda. Selanjutnya, Oposisi biner adalah sebuah konsep mengenai pola pengenalan manusia terhadap simbol dan makna akan kata. Konsep ini menjelaskan mengenai sesuatu yang selalu memiliki lawan akan terbentuk nilai dan makna sesungguhnya. Namun perlu diketahui oposisi biner bukan sesuatu yang berlawanan, melainkan pasangan yang bisa melengkapi dengan menemukan tujuan arah. Dalam sebuah forum diskusi pembelajaran online atau e-learning diskusi yang terjadi tidak lepas dari peran dosen dan mahasiswa. Ada peran yang secara struktur harus diambil masing-masing pihak untuk sebuah keberlangsungan forum diskusi. Dari sinilah hal tersebut kemudian memunculkan oposisi biner. Oposisi biner, sekali lagi, adalah sebuah konsep menarik yang dikemukakan oleh para filsufmengenai pola pengenalan manusia terhadap simbol dan makna akan kata.
Bagaimana menetukan tolok ukur akan sesuatu pun dikarenakan oposisi biner. Konsep ini adalah penjelasan mengenai suatu yang selalu memiliki lawan maka akan terbentuk nilai dan makna sesungguhnya.

\section{Hegemoni}

Istilah hegemoni berasal dari bahasa Yunani kuno yaitu 'eugemonia' Sebagaimana yang dikemukakan encylclopedia Britanica dalam prakteknya di Yunani, diterapkan untuk menunjukkan dominasi posisi yang diklaim oleh negara-negara kota secaara individual misalnya yang dilakukan opleh negara Athena dan Sparta terhadap negara-negara lain yang sejajar (Hendarto, 1993:73) sebagaimana diadaptasi oleh Mahadi. ${ }^{12}$ Adapun teori hegemoni yang dicetuskan Gramsci adalah sebuah pandangan hidup dan cara berpikiryang dominan, yang di dalamnya sebuah konsep tentang kenyataan disebarluaskan dalam masyarakat baik secara institusional maupun perorangan; (ideologi) mendiktekan seluruh cita rasa, kebiasaan moral, prinsip-prinsip religius dan politik, serta seluruh hubungan-hubungan sosial, khususnya dalam makna intelektual dan moral."

Berdasarkan pemikiran
Gramsci tersebut dapat dijelaskan
bahwa hegemoni merupakan suatu
kekuasaan atau dominasi atas nilai-nilai
kehidupan, norma, maupun kebudayaan
sekelompok masyarakat yang akhirnya
berubah menjadi doktrin terhadap
kelompok masyarakat lainnya dimana
kelompok yang didominasi tersebut
secara sadar mengikutinya. Kelompok
${ }^{12}$ Dwi Hatmoko Mahadi, Sumartini, and
Mulyono, "Hegemoni Moral Nyai Kertareja
Terhadap Srintil Dalam Novl Jentera Bianglala
Karya Ahmad Tohari Kajian Hegemoni Gramci,"
Jurnal Sastra Indonesia Vol. 3, No 1 (2014): 3.


yang didominasi oleh kelompok lain tidak merasa ditindas dan merasa itu sebagai hal yang seharusnya terjadi. Antonio Gramsci membangun suatu teori yang menekankan bagaimana penerimaan kelompok yang didominasi terhadap kehadiran kelompok dominan berlangsung dalam suatu proses yang damai, tanpa tindakan kekerasan. Media dapat menjadi sarana di mana satu kelompok mengukuhkan posisinya dan merendahkan kelompok lain. Proses bagaimana wacana mengenai gambaran masyarakat bawah bisa buruk di media berlangsung dalam suatu proses yang kompleks. Proses marjinalisasi wacana itu berlangsung secara wajar, apa adanya, dan dikhayati bersama. Khalayak tidak merasa dibodohi atau dimanipulasi oleh media. Konsep hegemoni menolong kita menjelaskan bagaimana proses ini berlangsung. Hegemoni menekankan pada bentuk ekspresi, cara penerapan, mekanisme yang dijalankan untuk mempertahankan dan mengembangkan diri melalui para korbannya, sehingga upaya itu berhasil dan mempengaruhi dan membentuk alam pikiran mereka. Melalui hegemoni, ideologi kelompok dominan dapat disebarkan, nilai dan kepercayaan dapat dipertukarkan. Akan tetapi, berbeda dengan manipulasi atau indoktrinasi, hegemoni justru terlihat wajar, orang menerima sebagai kewajaran dan sukarela.

Salah satu kekuatan hegemoni adalah bagaimana ia menciptakan cara berpikir atau wacana tertentu yang dominan, yang dianggap benar, sementara wacana lain dianggap salah. Media di sini dianggap secara tidak sengaja dapat menjadi alat bagaimana nilai-nilai atau wacana yang dipandang dominan itu disebarkan dan meresap dalam benak khalayak sehingga menjadi konsesus bersama. Sementara nilai atau wacana lain dipandang sebagai menyimpang. Hegemoni dipergunakan untuk menunjukkan adanya kelas dominan yang mengarahkan "tidak hanya mengatur" masyarakat melalui pemaksaan kepemimpinan moral dan intelektual. ${ }^{13}$

Hegemoni diatur oleh mereka yang oleh Gramsci disebut "intelektual organic". Mereka adalah tokoh moral dan intelektual yang secara dominan menentukan arah konflik, politik, dan wacana yang berkembang di masyarakat. Mereka bekerja untuk melanggengkan kekuasaan atas kelompok yang lemah. Dominasi "intelektual organic" diwujudkan melalui rekayasa bahasa sebagai sebuah kekuasaan. Melalui berbagai media bahasa ditunjukkan hadirnya kekuasaan dan pengaturan hegemoni tersebut. Berbagai kebijakan negara, misalnya, disampaikan dalam bahasa "untuk kepentingan bangsa di masa mendatang" atau "demi kemandirian bangsa" telah menghegemoni masyarakat untuk senantiasa menerima berbagai keputusan negara, yang merugikan sekalipun, demikian Beard. ${ }^{14}$ Fungsi lain hegemoni yakni, menciptakan cara berpikir yang berasal dari wacana dominan, juga media yang berperan dalam penyebaran wacana dominan itu. Hegemoni dipergunakan untuk menunjukkan adanya kelas dominan yang mengarahkan tidak hanya mengatur masyarakat melalui pemaksaan kepemimpinan moral dan intelektual (Storey, 2003:172). ${ }^{15}$

\footnotetext{
${ }^{13} \mathrm{~J}$ Storey, Teori Budaya Dan Budaya Pop: Memetakan Lanskap Konseptual Cultural Studies. Terjemahan Dede Nurdin (2003). (Yogyakarta: Qalam, 2003), 172.

${ }^{14}$ Beard. A., The Language of Politics. (London: Routledge, 2000), 2.

${ }^{15}$ Storey, Teori Budaya Dan Budaya Pop: Memetakan Lanskap Konseptual Cultural Studies. Terjemahan Dede Nurdin (2003)., 172.
} 


\section{Diskusi}

Diskusi berasal dari kata Latin, yakni discutio atau discusium yang berarti bertukar pikiran. Diskusi adalah sebuah interaksi komunikasi antara dua orang ataulebih/kelompok. Biasanya komunikasi antara mereka/ kelompok tersebut berupa salah satu ilmu atau pengetahuan dasar yang akhirnya akan memberikan rasa pemahaman yang baik dan benar. Diskusi bisa berupa apa saja yang awalnya disebut topik. Dari topik inilah diskusi berkembang dan diperbincangkan yang pada akhirnya akan menghasilkan suatu pemahaman dari topik tersebut. Lebih lanjut tentang diskusi, Namun, tidak semua proses yang menggunakan prinsip bertukar pikiran dapat disebut dengan diskusi. Proses bertukar pikiran yang dapat dikatakan sebuah diskusi merupakan bertukar pikiran yang terarah, ada proses perjalanannya, ada nada hasil yang dicapai.

Oleh karena itu, di dalam sebuah diskusi membutuhkan topik yang berguna untuk didiskusikan. Kegiatan diskusi ditujukan untuk memperoleh suatu kesepakatan, pengertian, dan keputusan bersama mengenai suatu topik atau masalah yang telah disepakati dari awal. Di dalam forum diskusi, adanya proses tanya jawab merupakan suat unsur yang sangat penting. Diskusi biasanya dilakukan oleh dua orang atau lebih. Namun, terdapat diskusi yang dilakukan oleh beberapa orang, yang disebut dengan diskusi kelompok. Di dalam diskusi kelompok, dibutuhkan seorang pemimpin diskusi yang bertugas untuk mengarahkan diskusi, merangsang minat anggota diskusi untuk berpendapat, membuka dan menutup diskusi, menengahi anggota diskusi yang berdebat, dan menyampaikan kesimpulan hasil diskusi.
Berikut merupakan pengertian diskusi dari beberapa ahli, yaitu menurut Moh.Uzer Usman, yang dinamakan dengan diskusi ialah suatu proses yang teratur dengan melibatkan sekelompok orang dalam interaksi tatap muka yang informal dengan berbagai pengalaman atau informasi pengambilan kesimpulan, atau pemecahan masalah. ${ }^{16}$ Hasibuan berpendapat bahwa yang dinamakan dengan diskusi merupakan suatu proses penglihatan yang melibatkan dua atau lebih individu yang berinteraksi secara verbal dan saling bertatap muka mengenai tujuan atau sasaran yang sudah tertentu melalui tukar menukar informasi mempertahankan pendapat, atau memecahkan masalah. ${ }^{17}$ Menurut Moh. Surya, diskusi merupakan suatu proses bimbingan dimana murid-murid akan mendapatkan suatu kesempatan untuk menyumbangkan pikiran masingmasing dalam memecahkan masalah bersama. $^{18}$

Dalam diskusi ini tertanam pula rasa tanggung jawab dan harga diri. Dengan melakukan diskusi, maka kita akan dapat menambah wawasan atau pengetahuan mengenai suatu permasalahan atau topik yang diangkat dalam proses diskusi, hal ini disebabkan karena di dalam proses diskusi, tidak hanya melibatkan satu pikiran saja, melainkan terdapat banyak pikiranpikiran yang tetap mengemukakan tentang suatu permasalahan tadi.

Sumber data pada penelitian ini adalah konten forum diskusi

${ }^{16}$ Usman Moh Uzer, Menjadi Guru Profesional. (Bandung: PT Remaja Rosdakarya, 2000), p. 4.

${ }^{17}$ Hasibuan and Mudjiono, Metode Pembelajaran. Jakarta: Bumi Aksara (Jakarta: Bimu Aksara, 2008), p. 20.

${ }^{18}$ Moh. Surya, Psikologi Pembelajaran Dan Pengajaran. (Bandung: Pustaka Bani Quraisy, 2004), p. 107. 
e-learning berupa chatting box yang berisi informasi keterlibatan dosen dan mahasiswa dalam diskusi pada kursus yang di-online-kan sebagaimana Sutopo (2002: 49) menyatakan bahwa sumber data merupakan bagian yang sangat penting bagi peneliti karena ketepatan memilih dan menentukan ketepatan dan kekayaan data atau informasi yang diperoleh. ${ }^{19}$ Dalam penelitian ini, peneliti menggunakan metode deskriptif kualitatif sebagaimana menurut Sugiyono, (2003:14) menyatakan bahwa, penelitian kualitatif adalah data kualitatif yang berbentuk kata, skema, dan gambar. ${ }^{20}$ Peneliti berusaha menganalisis data dengan semua nuansa, sedekat mungkin dengan bentuk aslinya. Menurut Bogdan dan Taylor (1975) dalam buku Moleong mengemukakan metode kualitatif sebagai prosedur penelitian yang menghasilkan data deskriptif berupa kata-kata atau lisan dari orang-orang dan perilaku yang dapat diamati. ${ }^{21}$ Berdasarkan pendapat di atas dapat dikemukakan bahwa metode deskriptif kualitatif adalah metode penelitian yang menghasilkan data deskriptif yang berbentuk kata, skema, dan gambar. Serta tidak memotong halaman cerita dan data lainnya dengan simbol-simbol angka. Mile dan Huberman seperti yang dikutip oleh Salim (2006: 20-24), menyebutkan ada tiga langkah pengolahan data kualitatif, yakni reduksi data (data reduction), penyajian data (data display), dan penarikan kesimpulan (conclusion

${ }^{19}$ Sutopo, Metodologi Penelitian Kualitatif: Dasar Teori Dan Terapannya Dalam Penelitian. (Surakarta: Sebelas Maret University Press, 2002), p. 49.

${ }^{20}$ Sugiyono, Metode Penelitian Bisnis. (Bandung: Pusat Bahasa Kemendiknas, 2003), p. 14.

${ }^{21}$ J. Moleong Lexy, Metodologi Penelitian Kualitatif. (PT Remaja Rosdakarya Media, 2004), p. 3. drawing and verification). ${ }^{22}$ Dalam pelaksanaannya reduksi data, penyajian data, dan penarikan kesimpulan/ verifikasi, merupakan sebuah langkah yang sangat luwes, dalam arti tidak terikat oleh batasan kronologis. Secara keseluruhan langkah-langkah tersebut saling berhubungan selama dan sesudah pengumpulan data, sehingga model dari Miles dan Huberman disebut juga sebagai Model Interaktif.

\section{Hasil Pembahasan}

Dalam menentukan posisi oposisi biner dalam konten forum diskusi e-learning berikut, peserta pertama adalah dosen dan peseta kedua adalah para mahasiswa. Data-data yang tersaji berupa Chatting box yang menunjukan proses diskusi secara online oleh kedua pihak pelaku diskusi perkuliahan online dalam hal menentukan topik diskusi dan respon yang menjadi tolok ukur keaktifan kedua pihak oposisi biner dan kemudian akan menjadi batasan dominasi atau hegemoni dari proses diskusi yang berlangsung.

Berikut adalah forum diskusi E-Learning yang dibuka dan atau diawali oleh pihak dosen sebagai participan forum diskusi. Yaitu melempar sebuah topik bahasan yang meminta participan lainnya dalam forum aktif menjawab dan mediskusikan.

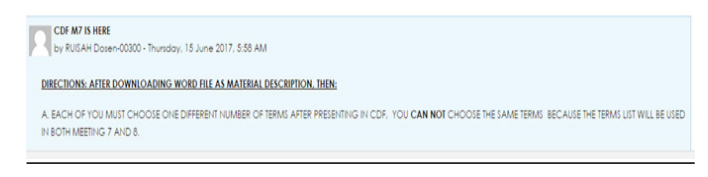

Figure 1

\footnotetext{
"Each of you must choose one different number of terms after presenting in

${ }^{22}$ Salim and Syahrum, Metodologi Penelitian Kualitatif. (Bandung: Ciptapustaka, 2006), 2024.
} 
CDF, Class Discussion Forum, You cannot choose the same terms because the term list will be used in both meeting 7 and 8."

Forum diskusi dalam perkuliahan online mewajibkan peserta saling berinteraksi setelah topik diberikan. Namun, pada data berikut menunjukkan adanya kekosongan respon dari peserta diskusi dan menjadikannya hanya sebagai forum dominasi satu pihak sebagaimana terlihat pada data berikut.

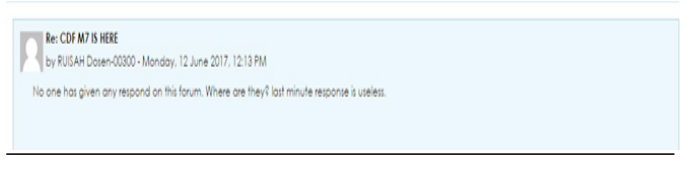

Figure 2

"No one has given any respond on this forum. Where are they? Last minute respond is useless."

Kepasifan peserta forum diskusi masih berlanjut ketika dalam forum, peserta pertama menyatakan ketiadaan respon atau balasan. Sebagaimana terlihat dalam data berikut.

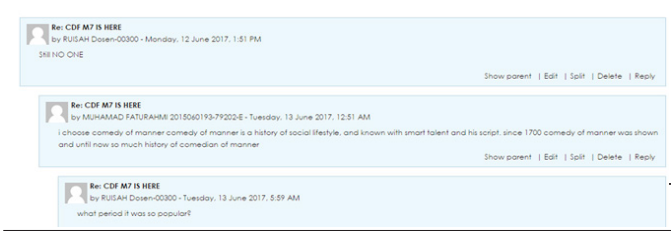

Figure 3

"Still no one."

"I choose comedy of manner. Comedy of manner is a history of social lifestyle, and known with smart talent and his script since 1700. Comedy of manner was shown and until now so much history of comedian of manner.

"What period was it so popular?"

Pada data 3, tersaji kotak percakapan diskusi oleh peserta satu dan peserta kedua lainnya yang memberi komentar pada sebuah topik yangtelah dipilih, namun tidak menunjukkan sebuah kegiatan diskusi melainkan lebih kepada menjawab pertanyaan dalam ujian tertulis. Dalam sebuah forum diskusi seharusnya ada kelekatan atau kelenturan dalam membicarakan sebuah topik. Hal ini kemudian terlihat dominasi peserta pertama yang kembali melempar pertanyaan untuk memancing respon peserta kedua. Dalam data tidak ada respon balasan yang menunjukan bahwa forum diskusi tetap didominasi oleh peserta pertama.

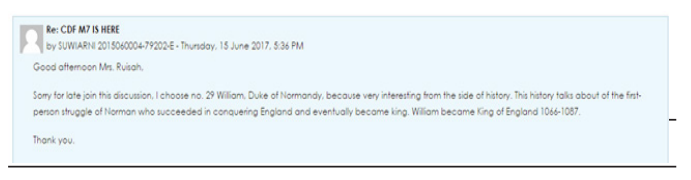

\section{Figure 4}

"Sorry for late join this discussion. I choose no. 29 William Duke of Normandy, because very interesting from the side of history. This history talks about the first person struggle of Norman who succeeded in conquering England and eventually became king. William became king of England 10661087."

\section{"Thank you."}

Pada data 4, peserta kedua forum diskusi menunjukkan kepasifannya dalam forum diskusi dengan memberi respon yang terlambat atau tidak pada live discussion di mana antara kedua partisipan harus saling merespon atau berdiskusi. Keaktifan peserta dalam forum diskusi perkuliahan online haruslah terjadi pada rentang waktu yang sama dan sedang berlangsung. Membalas dan menjawab seperti pada data empat di atas menjadikan esensi online 
learning khusus pada forum diskusi menjadikannye berubah secara makna dan tujuan. Sehingga, kondisi tersebut menjadikannya lebih seperti kegiatan berkirim pesan dan atau menjawab pertanyaan untuk terpenuhinya tugas.

Dalam hal ini kemudian, makin memperkuat posisi lemah antara oposisi biner peserta pertama dan kedua. Kecenderungan yang terjadi adalah tidak serasinya status oposisi biner yang seharusnya saling melengkapi meski sebagai oposisi. Dominasi dan hegemoni tetap menjadi bagian yang melekat pada peserta pertama.

\section{Data 5.}

Pada data 5, tersaji bagaimana peserta kedua dalam forum diskusi perkuliahan online tidak menyimak topik dan aturan dalam forum diskusi. Kegiatan yang berupa respon masih tetap sebagai kegiatan seperti hit and run.Lebih kepada aktifitas menggugurkan kewajiban dan pemenuhan eksistensi semata. Kesalahan merespon oleh peserta kedua pada data lima sama sekali tidak memancing respon peserta kedua lainnya sebagai bahan diskusi yang menarik, namun dengan segera diralat seperti kegiatan mejawab pertanyaan pada ujian tertulis pada pekan ujian tengah dan akhir semester. Tindakan meralat jawaban menjadikan gugurnya konsep opoisisi biner dalam forum diskusi, di mana proses interaksi langsung tidak berjalan. Diikuti oleh data 6 sebagai data sejenis:

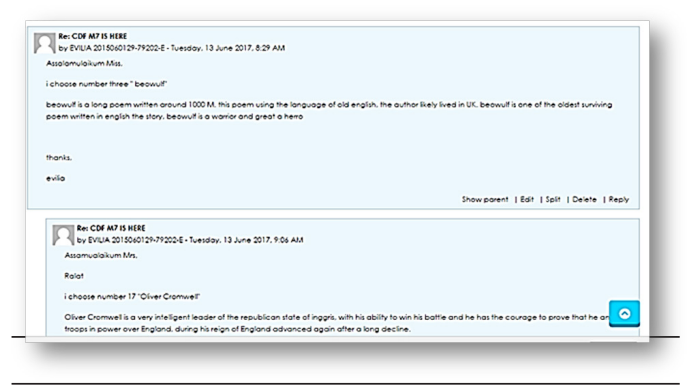

\section{Figure 5}

“Assalamualaikum Miss."

"I choose number three "Beowulf"."

"Beowulf is a long poem written around 1000M. This poem using the language of old English. The author likely lived in UK. Beowulf is one of the oldest surviving poem written in English the story, Beowulf is a warrior and great hero."

\begin{tabular}{l} 
"Thanks." \\
"Assalamualaikum Mrs." \\
\hline Ralat.
\end{tabular}

"Ichoose number 17 'Olover Cromwell"

"Oliver Cromwell is a very intelligent leader of the republic state of England, with his ability to win his battle and he has the courage to prove that he and his troops in power over England, during his reign of England advanced again other along decline." 


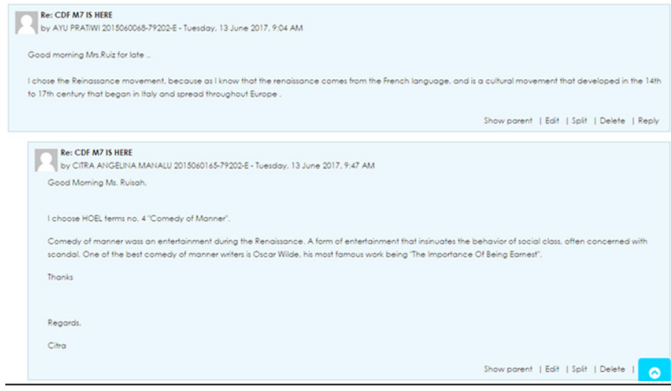

Figure 6

"I choose the Renaissance movement, because as I know that the renaissance comes from the French language, and it is a cultural movement that developed in the $14^{\text {th }}$ to $17^{\text {th }}$ century that began in Italy and spread throughout Europe."

"I choose HOEL terms no. 4 "Comedy of Manner".

"Comedy of manner was an entertainment during the renaissance. A form of entertainment that insinuates the behavior of social class often concern with scandal. One of the best comedies of manner writer is Oscar Wilde, his most famous work being 'The Importance of being Earnest'.,

"thanks."

Pada data 7 di bawah ini, forum diskusi seharusnya berjalan tanpa hegemoni atau dominasi satu pihak peserta diskusi, ketika peserta pertama merespon pernyataan peserta kedua dengan pertanyaan yang memancing opini. Hanya saja, peserta kedua tidak menanggapi.

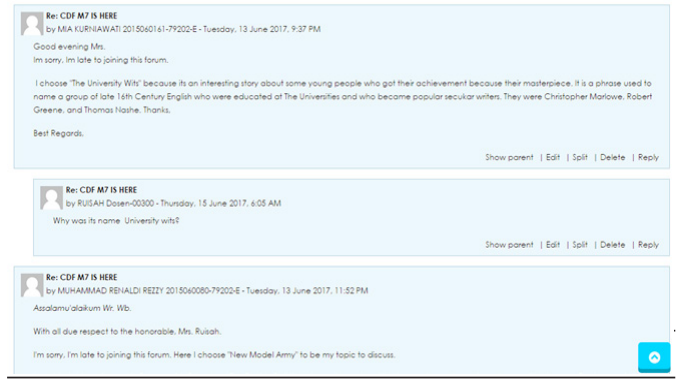

Figure 7

"Good evening Mrs."

"I'm sorry, I'm late to join this forum."

"I chose the university wits because it's an interesting story about some young people who got their achievement because their masterpiece. It is a phrase used to name of a group of late $16^{\text {th }}$ century English who were educated at the universities and who became popular secular writer. They were Christopher Marlowe, Robert Greene and Thomas Nashe. Thanks."

"Why was its name University Wits?"
"Assalamualaikum Wr.Wb."

"With all due respect to the honorable Mrs.

"I'm sorry; I'm late to join this forum. Here I choose "New Model Army" to be my topic to discuss."

Respon peserta pertama berupa pertanyaan pancingan, "Why was its name University Wits?" seharusnya ditanggapi oleh peserta kedua dengan jawaban yang bersifat opini terlebih dahulu dan akan dikomentari oleh peserta diskusi lain agar konsep forum diskusi dua sisi atau opisisi biner terpenuhi. Namun dari data tersaji, respon peserta kedua lainnya hanya menyampaikan 
kalimat penanda eksistensi saja tanpa melanjutkan atau terlibat aktif dalam forum diskusi yang sedang berlangsung. Data berikut menunjukkan pola dan pengulangan yang sama oleh peserta kedua forum diskusi.

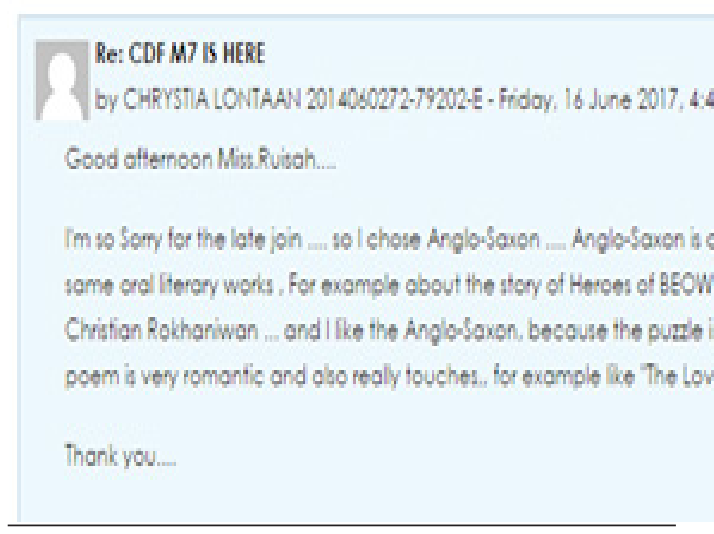

Figure 8

"Good afternoon Mis__,

I'm so sorry for the late join... so I chose Anglo-Saxon... Anglo-Saxon is another name of Old English Literature, AngloSaxon is an oral literary work, they also have the some oral literary works. For example about the story of heroes of BEOWULF. And this oral literature has been running for hundreds of years, and then written by Christian Rokhaniwan... and I like the Anglo-Saxon, because the puzzle is so strange and interesting. Short poems or lyrics of dramas with the theme of love... I think the poem is very romantic and also really touches. For example like 'The Lover's message'."

Data-data berikut ini diambil dari konten forum diskusi perkuliahan online dengan mata kuliah atau course yang berbeda dari data sebelumnya. Tetap dengan melihat peserta diskusi sebagai oposisi biner dosen dan mahasiswa. Peserta pertama adalah dosen, dan peserta kedua adalah sejumlah mahasiswa yang akan disebut peserta kedua lainnya.

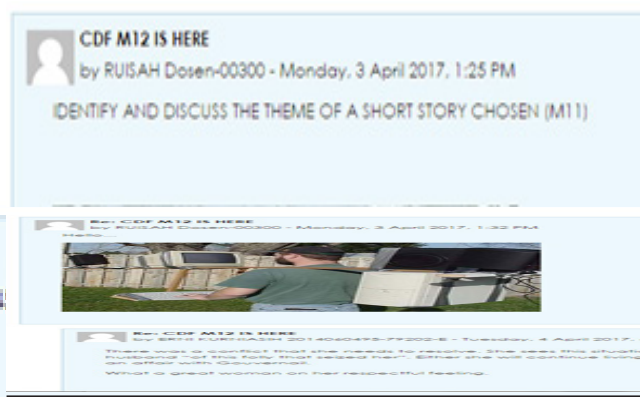

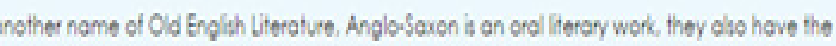
Figure 9 il theroture hes been running for hundreds of yeor, and then written by "Identify and discuss the theme of a short story chosen (M11)."

\section{"Hello..."}

Pada data 9, peserta pertama melemparkan sebuah topik diskusi dan membatasi subtopik diskusi. Pada chatting box bertuliskan "Helo.."(red:Hello), peserta pertama tidak mendapatkan respon langsung dari peserta kedua dan lainnya. Jeda atau kekosongan respon adalah bukti lain bahwa forum diskusi perkuliahan online hanya didominasi oleh peserta pertama.

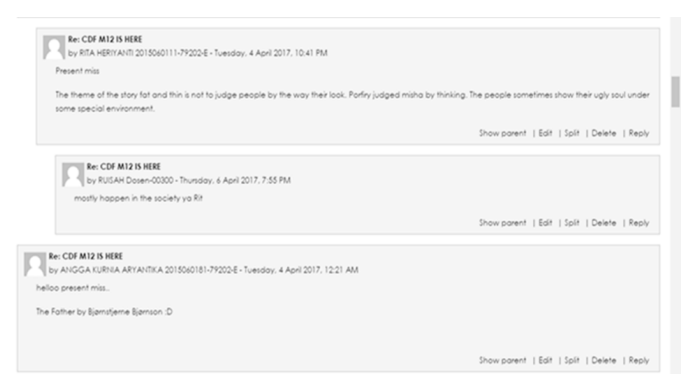

Figure 10

\section{"Present miss."}

The theme of the story flat and this is not to judge people by the way their look. Portray judge Misha by thinking. The people sometimes show their ugly 
soul under some special environment."

"Mostly happen in the society ya ."

"Hello present miss..."

'The Father by Bjornstjeme Bornson."'

Data 10 menyajikan upaya menjadikan forum diskusi menjadi aktif dan interaktif dengan respon-respon cepat yang memancing kembali opini atau paparan lanjutan dari peserta kedua dan lainnya. Namun, upaya tersebut kembali terputus ketika peserta kedua lainnya hanya menunjukkan presensi saja dalam forum. Sementara tanpa menunjukkan presensi sebenarnya peserta kedua dan lainnya sudah hadir. Kondisi yang diharapkan mampu dipenuhi oleh peserta kedua adalah aktif dalam bentuk komentar langsung pada setiap diskusi yang sedang dibahas dengan topik terpilih. Menunjukkan presensi tanpa menanggapi langsung pada topik diskusi kembali menjadikan forum diskusi kehilangan esensinya.

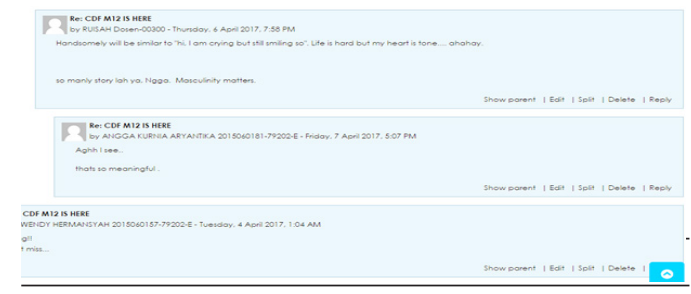

"Handsomely will be similar to ' $h i, \mathrm{I}$ am crying but still smiling so'. Life is hard but my heart is tone..."

"So manly story lah ya, Ngga. Masculinity matters.'

Data 11 yang menyajikan bahwa peserta kedua dan lainnya mengutamakan presensi dan respon hit and run saja.

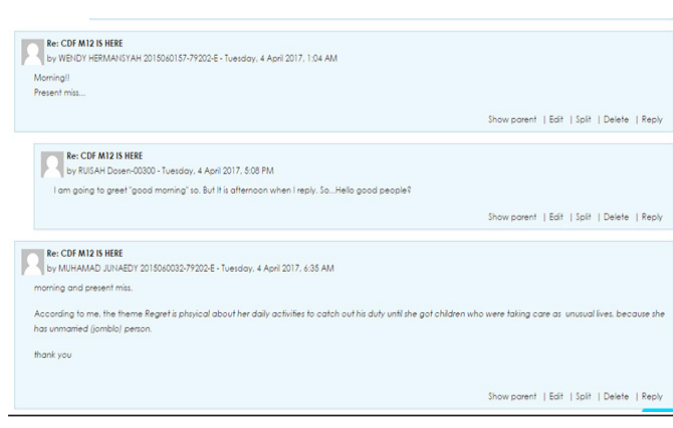

\section{Figure 11}

"Morning!!"

"Present Miss..."

'I am going to greet 'good morning' so. But this is afternoon when I reply. So... Hello good people."

"Morning and present miss."

"According to me, the theme Regret is physical about her daily activities to catch out his duty until she got children who were taking care unusual lives because she has unmarried (jomblo) person."

"Thank you."

Berikutnya adalah data 12 .

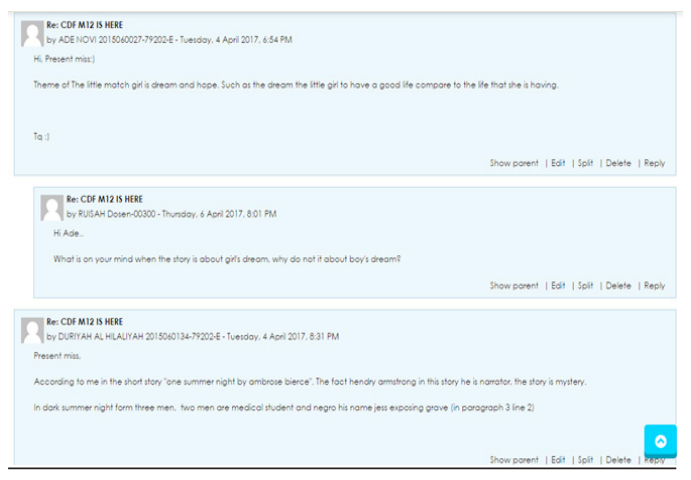

Figure 12

"Hi, present miss $\odot . "$ 
The of the little match girl is dream and hope. Such as the dream the little girl to have a good life compare the life that she is having."

Tq.

Hi,

"What is on your mind when the story is about girl's dream? Why do not it's about baby's dream?"

\section{"Present miss."}

"According to me in the short story 'One summer night by Ambrose bierce'. The fact Henry Armstong in this story he is narrator, the story is mystery. In the dark summer night from three men, two men are medical students and negro his name Jess exposing grave (in paragrapgh 3 line 2)."

Pada data 12, peserta kedua merespon forum diskusi dengan memberikan pemaparannya yan singkat tanpa menunjukkan apakah responnya bisa dibalas dan dikomentari peserta lain atau tidak. Kembali pada konsep hit and run yang banyak dilakukan oleh peserta kedua. Oleh peserta pertama, diskusi dihidupkan dengan memberikan pertanyaan pancingan agar peserta aktif mendiskusikan kembali topik terpilih. Hanya saja pada data di atas terlihat tidak ada respon balasan sebagai bentuk normal sebuah diskusi dan terpotong oleh kemunculan peserta kedua lainnya yang sama sekali tidak terkait topik diskusi yang sedang berlangsung.

Secara integral respon-respon forum diskusi perkuliahan daring yang menghasilkan konsep oposisi biner dapat dibaca dan tersaji dalam table berikut:
Table 1

\begin{tabular}{|c|c|}
\hline Data & Narasi \\
\hline 1 & $\begin{array}{l}\text { "Each of you must choose one } \\
\text { different number of terms af- } \\
\text { ter presenting in CDF, Class } \\
\text { Discussion Forum, You cannot } \\
\text { choose the same terms because } \\
\text { the term list will be used in } \\
\text { both meeting } 7 \text { and } 8 \text {. }\end{array}$ \\
\hline 2 & $\begin{array}{l}\text { "No one has given any re- } \\
\text { spond on this forum. Where } \\
\text { are they? Last minute respond } \\
\text { is useless." }\end{array}$ \\
\hline \multirow[t]{3}{*}{3} & "Still no one." \\
\hline & $\begin{array}{l}\text { "I choose comedy of manner. } \\
\text { Comedy of manner is a history } \\
\text { of social lifestyle, and known } \\
\text { with smart talent and his script } \\
\text { since } 1700 \text {. Comedy of manner } \\
\text { was shown and until now so } \\
\text { much history of comedian of } \\
\text { manner. }\end{array}$ \\
\hline & $\begin{array}{l}\text { "What period was it so popu- } \\
\text { lar?" }\end{array}$ \\
\hline \multirow[t]{2}{*}{4} & $\begin{array}{l}\text { "Sorry for late join this discus- } \\
\text { sion. I choose no. } 29 \text { William } \\
\text { Duke of Normandy, because } \\
\text { very interesting from the side } \\
\text { of history. This history talks } \\
\text { about the first person struggle } \\
\text { of Norman who succeeded in } \\
\text { conquering England and even- } \\
\text { tually became king. William } \\
\text { became king of England } 1066- \\
1087 . "\end{array}$ \\
\hline & "Thank you." \\
\hline
\end{tabular}




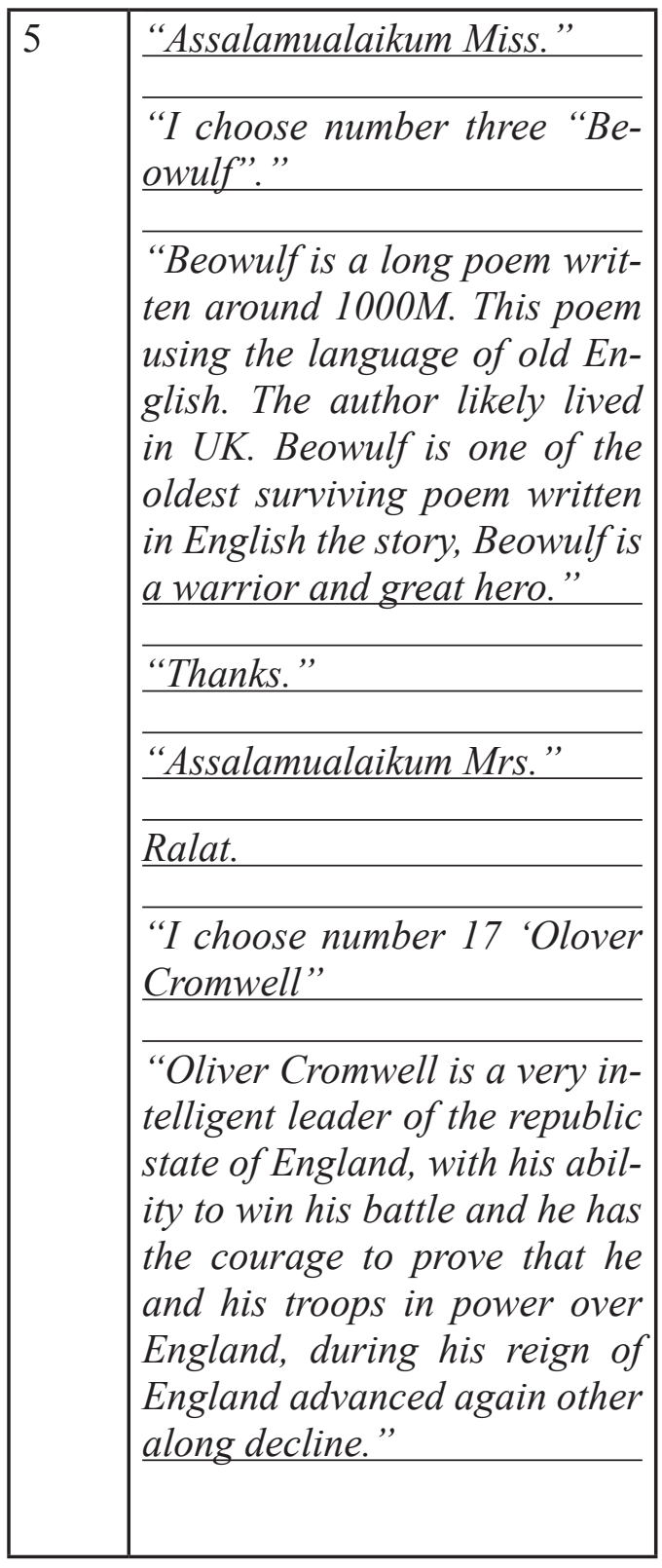

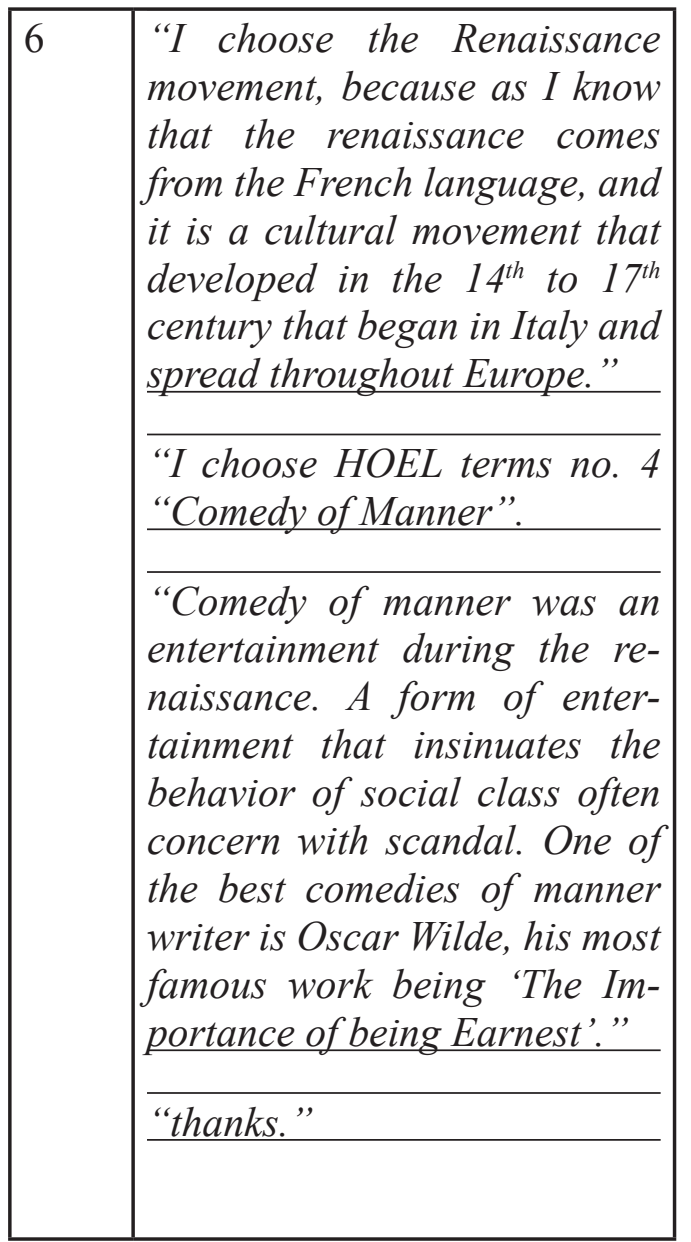




\begin{tabular}{|c|c|}
\hline & $\begin{array}{l}\text { "I'm sorry, I'm late to join this } \\
\text { forum." }\end{array}$ \\
\hline & $\begin{array}{l}\text { "I chose the university wits be- } \\
\text { cause it's an interesting story } \\
\text { about some young people who } \\
\text { got their achievement because } \\
\text { their masterpiece. It is a phrase } \\
\text { used to name of a group of late } \\
16^{\text {th }} \text { century English who were } \\
\text { educated at the universities } \\
\text { and who became popular sec- } \\
\text { ular writer. They were Christo- } \\
\text { pher Marlowe, Robert Greene } \\
\text { and Thomas Nashe. Thanks." }\end{array}$ \\
\hline & $\begin{array}{l}\text { "Why was its name University } \\
\text { Wits?" }\end{array}$ \\
\hline & "Assalamualaikum Wr.Wb." \\
\hline & $\begin{array}{l}\text { "With all due respect to the } \\
\text { honorable Mrs. }\end{array}$ \\
\hline & $\begin{array}{l}\text { "I'm sorry; I'm late to join this } \\
\text { forum. Here I choose "New } \\
\text { Model Army" to be my topic to } \\
\text { discuss." }\end{array}$ \\
\hline
\end{tabular}

\begin{tabular}{|l|l|}
\hline 8 & $\begin{array}{l}\text { "Good afternoon Mis } \\
\text { I'm so sorry for the late join... } \\
\text { so I chose Anglo-Saxon... An- } \\
\text { glo-Saxon is another name of } \\
\text { Old English Literature, An- } \\
\text { glo-Saxon is an oral literary } \\
\text { work, they also have the some } \\
\text { oral literary works. For exam- } \\
\text { ple about the story of heroes } \\
\text { of BEOWULF. And this oral } \\
\text { literature has been running for } \\
\text { hundreds of years, and then } \\
\text { written by Christian Rokha- } \\
\text { niwan... and I like the An- } \\
\text { glo-Saxon, because the puzzle } \\
\text { is so strange and interesting. } \\
\text { Short poems or lyrics of dra- } \\
\text { mas with the theme of love... I } \\
\text { think the poem is very roman- } \\
\text { tic and also really touches. For } \\
\text { example like 'The Lover's mes- } \\
\text { sage'." }\end{array}$ \\
\hline 9 \\
$\begin{array}{l}\text { "Identify and discuss the } \\
\text { theme of a short story chosen } \\
\text { (Ml1)." } \\
\text { "Hello..." }\end{array}$ \\
\hline
\end{tabular}




\begin{tabular}{|c|c|}
\hline \multirow[t]{5}{*}{10} & "Present miss." \\
\hline & $\begin{array}{l}\text { The theme of the story flat and } \\
\text { this is not to judge people by } \\
\text { the way their look. Portray } \\
\text { judge Misha by thinking. The } \\
\text { people sometimes show their } \\
\text { ugly soul under some special } \\
\text { environment." }\end{array}$ \\
\hline & $\begin{array}{l}\text { "Mostly happen in the society } \\
y a \quad . "\end{array}$ \\
\hline & "Hello present miss..." \\
\hline & $\begin{array}{l}\text { 'The Father by Bjornstjeme } \\
\text { Bornson." }\end{array}$ \\
\hline \multirow[t]{6}{*}{11} & "Morning!!" \\
\hline & "Present Miss..." \\
\hline & $\begin{array}{l}\text { 'I am going to greet 'good } \\
\text { morning' so. But this is after- } \\
\text { noon when I reply. So... Hello } \\
\text { good people." }\end{array}$ \\
\hline & "Morning and present miss." \\
\hline & $\begin{array}{l}\text { "According to me, the theme } \\
\text { Regret is physical about her } \\
\text { daily activities to catch out his } \\
\text { duty until she got children who } \\
\text { were taking care unusual lives } \\
\text { because she has unmarried } \\
\text { (jomblo) person." }\end{array}$ \\
\hline & "Thank you." \\
\hline
\end{tabular}

\begin{tabular}{|l|l|}
\hline 12 & \begin{tabular}{l} 
"Hi, present miss (-)." \\
The of the little match girl is \\
dream and hope. Such as the \\
dream the little girl to have a \\
good life compare the life that \\
she is having." \\
Tq. \\
\hline Hi, \\
"What is on your mind when \\
the story is about girl's dream? \\
Why do not it's about baby's \\
dream?" \\
"Present miss." \\
"According to me in the short \\
story 'One summer night by \\
Ambrose bierce'. The fact \\
Henry Armstong in this story \\
he is narrator, the story is mys- \\
tery. In the dark summer night \\
from three men, two men are \\
medical students and negro his \\
name Jess exposing grave (in \\
paragrapgh 3 line 2)."
\end{tabular} \\
\hline
\end{tabular}

\section{Penutup}

\section{Kesimpulan}

Dari hasil diskusi pada beberapa kursus dalam konten forum diskusi perkuliahan online, didapati bahwa peserta diskusi yang terdiri atas dosen dan mahasiswa sebagai opisisi biner, yakni sebuah sistem yang berusaha membagi dunia dalam dua klasifikasi yang berhubungan secara struktural. Dalam keterlibatan masing-masing peserta, terjadi dominasi atau hegemoni oleh satu peserta diskusi. Yang dimaksud dengan hegemoni adalah adalah sebuah pandangan hidup dan cara berpikir yang dominan, yang di dalamnya 
sebuah konsep tentang kenyataan disebarluaskan dalam masyarakat baik secara institusional maupun perorangan; mendiktekan seluruh cita rasa, kebiasaan moral, prinsip-prinsip religius dan politik, serta seluruh hubungan-hubungan sosial, khususnya dalam makna intelektual dan moral. Dalam hal ini, satu peserta forum diskusi mendominasi dalam dan peserta lainnya pasif dan mengikuti pola-pola dominasi. Dari data yang diperoleh dan dikaji dalam forum diskusi perkuliahan online dari para peserta disimpulkan bahwa terjadi hegemoni dalam klasifikasi oposisi biner di mana satu pihak peserta mendominasikan gagasannya terhadap peserta lain.

\section{Daftar Pustaka}

Ardiansyah, Ivan. Eksplorasi Pola Komunikasi Dalam Diskusi Menggunakan Moddle Pada Perkuliahan Simulasi Pembelajaran Kimia, Universitas Pendidikan Indonesia. Bandung: Universitas Pendidikan Indonesia, 2013.

Beard. A. The Language of Politics. London: Routledge, 2000.

Chandrawati, Sri Rahayu. "Pemanfaatan E-Learning Dalam Pembelajaran." Juran Untan Vol. 8 No 2 (2010). http://jurnal.untan.ac.id/.

Hartley, Darin E. "Selling E-Learning, American Society for Training and Development.," 2001.

Hasibuan, and Midjiono. Metode Pembelajaran. Jakarta: Bumi Aksara. Jakarta: Bimu Aksara, 2008.

Kamaraga, Hanny. "Belajar Sejarah Melalui E-Learning; Alternatif Mengakses Sumber Informasi Kesejarahan.” Jakarta: Inti Media,
2002.

Koran, C. Jaya Kumar. "Pengertian E-Learning Http://Www.Medukasi. Web.Id/2012/11/Pengertian-eLearning.Html," 2002.

Lexy, J. Moleong. Metodologi Penelitian Kualitatif. PT Remaja Rosdakarya Media, 2004.

Mahadi, Dwi Hatmoko, Sumartini, and Mulyono. "Hegemoni Moral Nyai Kertareja Terhadap Srintil Dalam Novl Jentera Bianglala Karya Ahmad Tohari Kajian Hegemoni Gramci." Jurnal Sastra Indonesia Vol. 3, No 1 (2014): 3.

Michael, Allen. "Michael Allen's Guide to Elearning. Canada: John Wiley \& Sons.," 2013.

Moh. Surya. Psikologi Pembelajaran Dan Pengajaran. Bandung: Pustaka Bani Quraisy, 2004.

Moh Uzer, Usman. Menjadi Guru Profesional. Bandung: PT Remaja Rosdakarya, 2000.

Putranto, Agus. "Perancangan Training Dengan E-Learning Pada Perusahaan Manufacture.” Junral Comtech Vol. 2, No. 1 Juni 2011 (2011): 317-24.

Salim, and Syahrum. Metodologi Penelitian Kualitatif. Bandung: Ciptapustaka, 2006.

Smaratungga. "Smaratungga, 2009. Manfaat E-Learning. Medica, Yogyakarta," 2009.

Storey, J. Teori Budaya Dan Budaya Pop: Memetakan Lanskap Konseptual Cultural Studies. Terjemahan Dede Nurdin (2003). Yogyakarta: Qalam, 2003.

Sugiyono. Metode Penelitian Bisnis. Bandung: Pusat Bahasa 
Kemendiknas, 2003.

Sutopo. MetodologiPenelitian Kualitatif: Dasar Teori Dan Terapannya Dalam

Penelitian. Surakarta: Sebelas

Maret University Press, 2002.

Winarno, and Setiawan Johan.

"Penerapan SistemE-Learning Pada

Komunitas Pendidikan Sekolah

Rumah (Home Schooling).” Jurnal

ULTIMA InfoSys Vol IV, No, 1

(June 2013): 45. 